\title{
Protecting Growth Options in Dynamic Markets: The Role of Strategic Disclosure IN INTEGRATEd INTELLECTUAL Property StRATEgies
}

\author{
Tilo Peters \\ Jana Thiel \\ Christopher L. Tucci
}

\begin{abstract}
Given recent developments in information technology and intellectual property (IP) legislation, technology firms may benefit from an integrated IP strategy that combines patenting with strategic disclosure. This article presents a series of cases that introduce various aspects of strategic disclosure and provide a framework for how and when such practices may be merited as part of an integrated IP strategy. To help CEOs decide on the economics and efficiency of the practice, practical guidelines are provided for when it might be a useful complement to the firm's other IP management practices. (Keywords: Intellectual Property, Patents, Innovation Management)
\end{abstract}

"The underlying reason for strategic disclosure is, of course, to create prior art, but in one technology field we are directed toward our direct competitors, and in the other field we are more oriented to the next level of the value chain, where you create disclosure to have freedom to operate and not be bound to one of the different partners in the value chain. So if they file before you they might block you and get an exclusive arrangement, which for a big chemical company is something you're not really looking for." ${ }^{\prime}$

hen German multinational BASF develops a new chemical or compound, the company has a number of factors to take into consideration. Using modern computational analysis, it is easy to determine with which substances a chemical will react, but without further testing, the utility of those reactions is unknown. Therefore, a novel chemical compound may well be patentable, but the secondary products are not immediately so. ${ }^{2}$ By strategically disclosing the potential secondary products, BASF effectively extends the scope of a patented product, and thus creates options for "value transportation" as outlined by Conley et al. in this issue. ${ }^{3}$ In other situations, BASF offers products in highly competitive, fast-paced industries with rapidly changing product compositions. The various permutations of, for instance, a novel pigment (e.g., cream, gel, spray, and pencil) are practically limitless. Naming each of them in a patent may take longer than any one of them stays in fashion; and by the time competitors see the patent application, several 
Tilo Peters is a doctoral student researcher at École Polytechnique Fédérale de Lausanne (EPFL) in the Chair of Corporate Strategy \& Innovation in Lausanne, Switzerland. <tilo.peters@epfl.ch> Jana Thiel is a post-doctoral researcher at ESADE Business School in Barcelona, Spain. <jana.thiel@esade.edu>

Christopher L. Tucci is Professor of Management of Technology and holds the Chair in Corporate Strategy \& Innovation at École Polytechnique Fédérale de Lausanne (EPFL) in Lausanne, Switzerland. <christopher.tucci@epfl.ch>

fashion cycles will have passed. By revealing the patented product and its plethora of consumer uses, BASF preempts its competitors and directs its customers to the potential of the BASF product.

The above example illustrates a few of the many ways in which strategic disclosure-the act of creating novelty-destroying prior art in order to prevent or impede another agent from being able to obtain IP protection on the same or a similar invention or artistic or literary creation ${ }^{4}$ - can be used as part of an integrated intellectual property (IP) strategy. In this article, we examine how firms can integrate disclosure with patenting. Given recent shifts in legislation, in the availability of information, and in the changing competitive landscape, prior rationales for patent-centric regimes may no longer be exclusively true. Today's executives may be well served to consider adding strategic disclosure to their arsenal of IP tools.

\section{IP as a Resource to Serve a Firm's Strategic Motivations}

Although patents and intellectual property have long been operational elements in businesses, using IP protection as a strategic tool-in particular, matching it to an organizational or industry dynamic - has only recently gained greater traction. ${ }^{5}$ In many cases, such discussions largely focus on patents and exclusive property rights as drivers of value capture. Yet three important developments stand out as factors that have made markets-especially markets for ideas-more dynamic. First, the proliferation of the Internet means that information is available both in terms of quantity and geographic reach that were unthinkable just a decade ago. Second, the creation of prior art and publication databases that provide patent examiners around the world instant access to disclosed inventions makes prior art search much easier. ${ }^{6}$ Third, the recent change in the U.S. patent law from firstto-invent to first-inventor-to-file that brings the U.S. code in line with much of the rest of the world ${ }^{7}$ has implications for firms' procedures with regard to disclosing inventions. ${ }^{8}$ Add to these factors the context of an increasing backlog of patent applications, and one has a recipe for dynamic markets riddled with uncertainty. ${ }^{9}$ These interrelated developments offer both opportunities and risks for obtaining, controlling, and defending proprietary knowledge, and require firms to rethink how they manage patenting and non-patenting practices. As a result, it has become more difficult for a firm to achieve an exclusive market position for long periods of time. In particular, less-powerful market actors-e.g., small and medium-sized firms, new entrants, corporate spinoffs, and trailing competitors-may seek freedom to operate (FTO) rather than exclusivity in an effort to tilt dynamic markets in their favor. ${ }^{10}$

Given these dynamic changes in industry and increasing uncertainty in the IP realm, technology firms may benefit from an integrated IP strategy that combines patenting with strategic disclosure. Such an integrated IP regime can efficiently protect FTO under technological and market uncertainty, strengthen 
the market position of a firm, and secure growth options. While large firms have long been using strategic disclosure (e.g., IBM, Xerox, Siemens, Motorola, Yahoo, Cisco, Lenovo, just to name a few), it is perplexing why this practice is not more widespread. Recent research indicates that, outside of the community of primarily large firms that already use it, only $36 \%$ of firms are aware of the practice of strategic disclosure, and less than one third of those have an expressed interest in using it as a tool in their IP management. ${ }^{11}$ Even in the academic literature, studies of the strategic use of disclosure are scant. ${ }^{12}$ This implies an underutilized potential for new approaches to effectively align IP management and firm strategy, and it appears to be driven largely by a lack of awareness as well as a lack of procedural knowledge of how to exploit the specific economics of non-patenting strategies.

Although both academic and practitioner work tend to focus on patenting as a means of protecting a firm's market advantage, findings indicate that, for large firms, only about $10 \%$ of their IP portfolios directly serve the commercialization of their products, ${ }^{13}$ while the remaining portion serves more for licensing, blocking, or other purposes. ${ }^{14}$ These excess patents serve important purposes for large firms, yet evidence suggests that the majority of firms-especially new entrants in the form of independent startups or corporate spin-offs or other smaller firms-cannot afford such excessive patenting, as they tend to have fewer resources. ${ }^{15}$ For those well versed in the legalities of patents, FTO is a document that holds a finding by a patent attorney or other researcher stating that the firm's IP portfolio does not infringe on extant IP and that the firm should have the right to operate freely, i.e., with minimal exposure to infringement litigation. This somewhat technical view should, however, not be confused with the strategic concept of FTO and its particular ability to protect value creation options. While some firms may consider having the power to prevent others from copying inventions to be an important motive, ${ }^{16}$ many other actors are predominantly interested in a somewhat broader concept of FTO: the ability to compete in a fair marketplace on the merits of the product without being excluded by opportunistic actors and frivolous patent litigation.

Those firms that do focus on exclusivity rather than FTO tend to concentrate their attention on just two IP mechanisms: patents and trade secrets. There are, however, a host of other mechanisms available-such as exploiting lead-time advantages or building strategies around complementary assets-that help firms appropriate value from their inventions. This issue contains several examples of such strategies, notably the value appropriation framework by Conley et al. as well as Chesbrough and Chen's work on leveraging dormant technologies. ${ }^{17}$ Adding to Oberholzer-Gee and Fisher's overview of strategic options in IP management, ${ }^{18}$ we posit that patents do not serve all those purposes equally, effectively, or efficiently. Combining and orchestrating the variety of available mechanisms is indeed of key importance. Today, a firm's IP strategy not only has to secure access to technological knowledge, but also needs to serve the strategic intentions and motivations of a firm. IP mechanisms serve many purposes, in particular: ${ }^{19}$

- owning exclusive rights to commercialize an invention,

- preventing others from copying or imitating an invention or product, 
- preempting competitors in a development race,

- ensuring freedom to operate, or

- signaling technological strength.

As this issue's collection of advances in new IP strategies highlights, a firm's appropriability and commercialization motivations, its business model, and its product development approach need to be a defining core of today's IP strategy. Below, we introduce and demonstrate different aspects of disclosing an invention to the public and how it can be used strategically in conjunction with other mechanisms to support and strengthen the market position of a firm.

\section{Strategic Disclosure}

Strategic disclosure pushes the envelope of what is novel and obvious, ${ }^{20}$ meaning that the next inventor will have to go that much further to justify a patent. Disclosing an invention to the public effectively establishes distinct boundaries of what cannot be within any private IP right (IPR), ${ }^{21}$ and thus clearly belongs within the realm of IPRs and should be an integral part of today's IP management. Not all disclosure is strategic, though (see Figure 1). It is important to approach disclosure issues with forethought because inadvertent disclosure can be damaging to the firm.

FIGURE I. Examples of Four Types of Disclosure

\begin{tabular}{|c|c|c|}
\hline 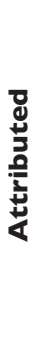 & $\begin{array}{l}\text { - Single or limited-print } \\
\text { text placed in reference } \\
\text { section of library. } \\
\text { - Disclosure posted on a } \\
\text { bulletin board in front of } \\
\text { a company headquarters, } \\
\text { photographed, then } \\
\text { removed. } \\
\text { - Prototype kept in 'public' } \\
\text { laboratory or facilities }\end{array}$ & $\begin{array}{l}\text { - Patents } \\
\text { - White papers } \\
\text { - Websites } \\
\text { - Journal articles } \\
\text { - Press releases } \\
\text { - Prior art databases }\end{array}$ \\
\hline 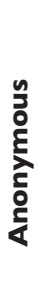 & $\begin{array}{l}\text { - Technical article written } \\
\text { in a foreign language and } \\
\text { published in obscure } \\
\text { newspapers or journal } \\
\text { - Doctoral dissertation } \\
\text { without corporate } \\
\text { attribution, indexed in a } \\
\text { university library }\end{array}$ & $\begin{array}{l}\text { - Prior art database or } \\
\text { journal such as IP.com or } \\
\text { Research Disclosure } \\
\text { - Scientific journal article }\end{array}$ \\
\hline & Obscured & Overt \\
\hline
\end{tabular}


While many people may think that prior art is established solely by publishing, it is also derived from any representation of the technology or idea. This representation can come in the form of prototypes, product brochures, specification sheets, web pages, presentations, conversations in public places, or, in the case of processes, even in an end product that bears witness to it. Companies have used such disclosures to invalidate the patents of competitors on the basis of prior art that the patent holder itself created.

\section{Non-Pecuniary Benefits of Strategic Disclosure}

Strategic disclosure, in contrast to patenting, has no limiting prerequisites such as novelty, utility, and non-obviousness. Furthermore, it is immediately accessible, whereas patents have a pendency period of at least 18 months. During this blackout period, a patent application is not visible as prior art. ${ }^{22}$ If another patent is filed during that time, it may be considered separately, resulting in two patents initially being issued for the same invention. Even if the examiner is reviewing both applications at the same time, any variation may still be regarded as sufficiently novel and lead to issuance of the patent. In this case, the very mechanism that is intended to provide the inventor with a benefit becomes a liability, particularly in dynamic markets where patent races are common. This increases uncertainty and can lead to costly, drawn-out legal battles. By contrast, all major publishing services allow patent examiners immediate access to their prior art databases and journals, so that such publication can be used to invalidate a patent application in the examination process if it predates a competitor's filing.

Those same dynamic markets also have secondary effects. Undoubtedly central to the operational needs of any firm is the collection of tacit knowledge relating to processes and procedures specific to its product line. Prudent firms will codify these internally as trade secrets. These secrets, provided they remain secret, have value to the firm that can last well beyond the typical duration of a patent. They provide, however, no protection against independent invention or grounds for invalidating a patent based on such. ${ }^{23}$ While we do not suggest that strategic disclosure should necessarily displace trade secrecy, evidence suggests that the risk of parallel invention and the increasing mobility of inventors and key personnel ${ }^{24}$ pose a challenge to enforcing trade secrecy.

Due to wide-ranging debates over the optimal nature of patent scope under policy regimes, patenting authorities have sought to limit the number of independent claims in patent applications. ${ }^{25}$ However, as we will see below, by using strategic disclosure a firm can project additional claims beyond those officially granted in a patent. Committing an incremental invention to the state of the art accomplishes two things: it prevents third parties from patenting that as part of some greater invention, and it pushes the envelope of what is novel and obvious. Thus, even if one cannot obtain a patent to keep competitors at bay, one can restrict their efforts to gain a dominant position. ${ }^{26}$

Another convenience emerges from the variety of anonymous methods to file strategic disclosures. Patent applicants are openly identified and thus, by 
studying the enabling information, outside parties may be able to infer the direction a firm's research is taking. ${ }^{27}$ Through anonymous strategic disclosure, firms can successfully disguise their strategic intent by breaking up publications into smaller elements, parsing them out to different outlets, mixing anonymous and attributed publications, and even contributing elements of disinformation ("red herrings"), thus making it difficult for curious competitors to re-assemble the information and draw valuable insights.

\section{Pecuniary Benefits of Strategic Disclosure}

One of the prime reasons that firms may consider publishing in addition to patenting is that the latter is a time-consuming and complex process, which ties up considerable resources. Although patent filing fees are relatively reasonable-for SMEs about $\$ 500$ for filing and examination and another $\$ 5,000$ in maintenance fees over the lifetime of the patent ${ }^{28}$ — very few individuals or firms have the training or inclination to prepare and convey the patent application through the process. By adding the expense of a patent attorney (the average patent requires 20-25 hours for a skilled patent attorney to draft, not to mention the inevitable office actions required to clear up discrepancies brought up by the examiner) legal fees for patent preparation go easily up to \$10,000-\$30,000 per patent for just the United States. ${ }^{29}$ Since this process must be repeated in each patenting jurisdiction, the cost of effective global coverage for a patent is many multiples of that amount. Given that most products represent an integrated bundle of IP, the possibility of obtaining comprehensive protection for a given product is well beyond the capabilities of many smaller actors. ${ }^{30}$ Strategic disclosure, by contrast, has much lower fee requirements: The major service providers charge amounts of a few hundred dollars per publication. Since there are no particular formatting requirements, multiple publications can be filed for much less than the cost of preparing a single patent. In addition, one publication establishes prior art worldwide, making strategic disclosure a huge multiplier in comparison to the cost of global patent coverage.

To summarize, the current idiosyncrasies of the patent system-notably its 18-month review period, the limits on the number of claims, restrictive patentability criteria, and lastly the enormous cost of global protection-limits the strategic flexibility that many firms may need today to succeed in the marketplace. In the following cases, we provide examples of the conditions under which the practice of strategic disclosure preserves strategic flexibility and growth options in commercializing inventions.

\section{Illustrative Case Studies}

To explore the conditions and the manner in which firms have integrated strategic disclosure into their IP strategy, we examine the innovation practices of four companies that vary in size, geographic location, and their strategic use of disclosure, as summarized in Table 1 . We chose these cases for their exemplary capacity to illustrate four central concepts in which firms may derive strategic benefit from integrating strategic disclosure into their IP regimes. We differentiate these concepts by the intent behind the use of strategic disclosure. 
TAB LE I. Description of Company Cases

\begin{tabular}{|c|c|c|c|c|}
\hline $\begin{array}{l}\text { Company } \\
\text { Name }\end{array}$ & Flisom & $\begin{array}{l}\text { Perfect Point } \\
\text { EDM }\end{array}$ & $\begin{array}{l}\text { Natural } \\
\text { Dental } \\
\text { Implants }\end{array}$ & Innocentive \\
\hline Domain & Flexible Solar Panels & $\begin{array}{l}\text { Machining } \\
\text { Equipment }\end{array}$ & Medical Devices & $\begin{array}{l}\text { Innovation } \\
\text { Intermediary }\end{array}$ \\
\hline $\begin{array}{l}\text { Strategic } \\
\text { Motivation }\end{array}$ & $\begin{array}{l}\text { International } \\
\text { expansion }\end{array}$ & $\begin{array}{l}\text { Organic (resource- } \\
\text { efficient) growth of } \\
\text { the firm }\end{array}$ & $\begin{array}{l}\text { Position company as } \\
\text { attractive acquisition } \\
\text { target }\end{array}$ & $\begin{array}{l}\text { Enhance customers' } \\
\text { ability to enact } \\
\text { solutions }\end{array}$ \\
\hline $\begin{array}{l}\text { Technology } \\
\text { Strategy }\end{array}$ & $\begin{array}{l}\text { Sell production } \\
\text { machinery B2B and } \\
\text { retain right to } \\
\text { develop future } \\
\text { technology }\end{array}$ & $\begin{array}{l}\text { Preserve } \\
\text { technological option } \\
\text { to pursue }\end{array}$ & $\begin{array}{l}\text { Establish } \\
\text { technological } \\
\text { leadership }\end{array}$ & $\begin{array}{l}\text { Clients use } \\
\text { crowdsourcing, } \\
\text { open Innovation } \\
\text { platform }\end{array}$ \\
\hline Actions & $\begin{array}{l}\text { Publish prior } \\
\text { knowledge to } \\
\text { establish } \\
\text { technological base } \\
\text { Publish nascent } \\
\text { technological } \\
\text { discoveries to } \\
\text { preserve right to } \\
\text { pursue in future }\end{array}$ & $\begin{array}{l}\text { Secure core } \\
\text { technology by } \\
\text { proprietary IPR. } \\
\text { Publish process and } \\
\text { method of tertiary } \\
\text { market opportunity } \\
\text { for patented primary } \\
\text { technology }\end{array}$ & $\begin{array}{l}\text { Publish patent day } \\
\text { after application } \\
\text { submission } \\
\text { Preempt } \\
\text { competitors by } \\
\text { publishing early, } \\
\text { thereby discourage } \\
\text { others from } \\
\text { pursuing } \\
\text { development. }\end{array}$ & $\begin{array}{l}\text { By ensuring that } \\
\text { challenge call has } \\
\text { complete } \\
\text { background on } \\
\text { existing knowledge, } \\
\text { challenge document } \\
\text { may establish prior } \\
\text { art and ensures } \\
\text { customer firm FTO }\end{array}$ \\
\hline $\begin{array}{l}\text { Integrated IP } \\
\text { Strategy }\end{array}$ & $\begin{array}{l}\text { Reveal-Level \& } \\
\text { Reveal-Patent }\end{array}$ & Patent-Extend & $\begin{array}{l}\text { Patent-Reveal \& } \\
\text { Patent-Extend }\end{array}$ & Reveal-Patent \\
\hline
\end{tabular}

Strategic disclosure can be used to reveal any form of prior art, both patented and not patented, and it can find application either alone or in direct relation to specific patents. If used in relation to specific patents, multiple intentions can be pursued. First, firms may use strategic disclosure to enhance the benefits of an associated patent, i.e., extend the scope of a patent by effectively adding claims to the patent or by stating alternative potential markets or uses for a technology; both of these would be patent-extend strategies. ${ }^{31}$ Firms may also choose strategic disclosure to reveal the contents of an associated patent prior to official publication, referred to as a patent-reveal strategy. Early revealing of a patent application allows firms to signal early technological advances and potentially discourage competitive development. ${ }^{32}$ Strategic disclosure can also be used to lay the groundwork for follow-on (collaborative) innovation, i.e., strategically establish common prior art as a basis for patents filed for later developments, which we refer to as a reveal-patent strategy. If used without explicit reference to a patent, strategic disclosure serves multiple purposes, most notably, and widely known, it secures FTO when patents are difficult, impossible, or otherwise not practical to obtain. Thus, in this article we also highlight the use of such reveal-level strategies (as in leveling the playing field) in making less visible prior art more prominently available to strengthen the future options of a company. Table 2 summarizes those four mechanisms and their benefits. 
TABLE 2. Strategies for IP Disclosure

\begin{tabular}{|c|c|c|}
\hline Strategy & What It Is & Benefits \& Applicability \\
\hline Reveal-Level & $\begin{array}{l}\text { Disclose prior art (including } \\
\text { "ancient" art) to prevent others } \\
\text { from patenting }\end{array}$ & $\begin{array}{l}\text { - Ensure that obscure prior art is in the open } \\
\text { - Prevents competitors "grandfathering" prior art as } \\
\text { - part of patent claims } \\
\text { - Refreshes old art in examiners' awareness } \\
\text { - Patent potential has low NPV } \\
\text { - Disclosure as a form of Real Option }\end{array}$ \\
\hline Reveal-Patent & $\begin{array}{l}\text { Disclose prior art, patents, and } \\
\text { techniques to establish a level } \\
\text { playing field and prepare common } \\
\text { ground for subsequent invention } \\
\text { that is intended to be patented }\end{array}$ & $\begin{array}{l}\text { - Enable a creative commons } \\
\text { - Possibly a market in future where patent would } \\
\text { lead to a market > } 10 \text { years } \\
\text { - Immature / uncertain future market } \\
\text { - Useful in collaborative ventures } \\
\text { - Establish the baseline technology standard for } \\
\text { Open Innovation partnerships }\end{array}$ \\
\hline Patent-Reveal & $\begin{array}{l}\text { Patent, then reveal during } \\
\text { I8-month blackout window }\end{array}$ & $\begin{array}{l}\text { - Avoid conflicts about prior art } \\
\text { - In a technology development race } \\
\text { - To signal superiority and force rivals to move on } \\
\text { - May help when seeking to establish dominant design }\end{array}$ \\
\hline Patent-Extend & $\begin{array}{l}\text { Patent technology, then disclose } \\
\text { possible applications, } \\
\text { permutations, modifications, etc. }\end{array}$ & $\begin{array}{l}\text { - Strong core patent } \\
\text { - In place of Device + Method patents } \\
\text { - When applications/methods may not qualify as } \\
\text { claims (marginal inventive step, unknown utility) } \\
\text { - Unable to move into multiple markets } \\
\text { simultaneously } \\
\text { - Protect entrepreneurial options }\end{array}$ \\
\hline
\end{tabular}

\section{Flisom-Flexible Solar Panels}

Flisom, a firm specializing in thin-film photovoltaic technology, holds the record for flexible solar-cell efficiency and owns patents for methods and devices relating to roll-to-roll manufacturing of photovoltaic modules. The professors and researchers who founded the company as a spin-out from a university research center $^{33}$ had not concentrated their efforts on patenting because they felt that they had simply optimized processes and technologies that were already known through scientific literature. They initially felt that their tacit knowledge relating to processes and methods was the key to the potential success of the firm. However, they soon learned that simply having superior knowledge would not ensure success in an increasingly competitive industry.

\section{Competitive Environment and Strategic Motivations of the Company}

Based in Switzerland, Flisom could not benefit from the large loans or subsidies that solar cell manufacturers in the U.S. and China are known to enjoy, and despite having market-leading technology, it was questionable whether it could 
expand its production enough to benefit from economies of scale. Faced with this problem, the options were either to become a manufacturer of products for a niche market, or to perfect the machines capable of producing the superior photovoltaics and sell those to product manufacturers. In order to sustain the latter strategy, the firm had to have a technology pipeline that would allow it not only to market its current technology, but also to have an ongoing stream of innovations to supply future generations of machines.

While a firm producing completely in-house would be able to hold process details secret, selling the machines moved the company into a different domain. Since a machine, once in a customer's hands, could be copied or technologies therein could be inferred, reverse engineered, or even patented, Flisom had to recalibrate its strategy since trade secrets and tacit knowledge could not adequately protect its position. Looking at the strategic options, CEO Anil Sethi realized that the firm had to structure its IP portfolio to secure and move beyond the knowledge base of its founding team. The new technical know-how would require some combination of process enhancement and accurate process replication. Therein, says Sethi, lay the challenge:

"The scientists find the concept of the pilot and manufacturing very prosaic and boring, not realizing that this is absolutely critical to get stable manufacturing, which is what you need to be able to provide the product a million or 100 million times a year of the same quality. And there's a lot of knowledge in those machine designs that you can capture and if you capture it properly and if you have a concerted strategy, you could end up moving up the value chain." ${ }^{34}$

\section{IP Strategy- "The Art of the Possible"}

Contrary to popular belief, patents are not the engine of innovation; they are only the means by which inventions are integrated into the collective knowledge known as "prior art." ${ }^{35}$ It is by the granting of a limited monopoly whereby society convinces inventors to reveal their proprietary knowledge, and it is this knowledge that fuels the engine of ongoing innovation. However, as the density of this knowledge base increases, it becomes harder to judge what is novel and what has simply been forgotten ${ }^{36}$ or was never documented in sufficient technical detail. ${ }^{37}$ Likewise, many products and technologies have wallowed in obscurity because they were either released to market before their time or held secret by initial inventors who lacked the resources to fully develop them. It was these "holes" in the state-of-the-art with which Flisom had to contend.

The Flisom team was working with what it considered to be knowledge in the public domain; however, those assumptions had to be tested and evaluated lest the company find itself threatened with infringement for using such knowledge. So Flisom's CEO Sethi hired a person with a Ph.D. in physics who was knowledgeable in the art to inventory all of the practices, methods, and technologies at use within Flisom to determine what was novel, what had business potential, what was established as prior art, and where the holes in prior art were. With the help of engineers, the scientists were able to optimize the process area, while still having the time and inclination to do what scientists do best, look at the cutting-edge of knowledge. 
FIGURE 2. Flisom's Integrated IP Strategy with Publications for the "Art of the Possible"

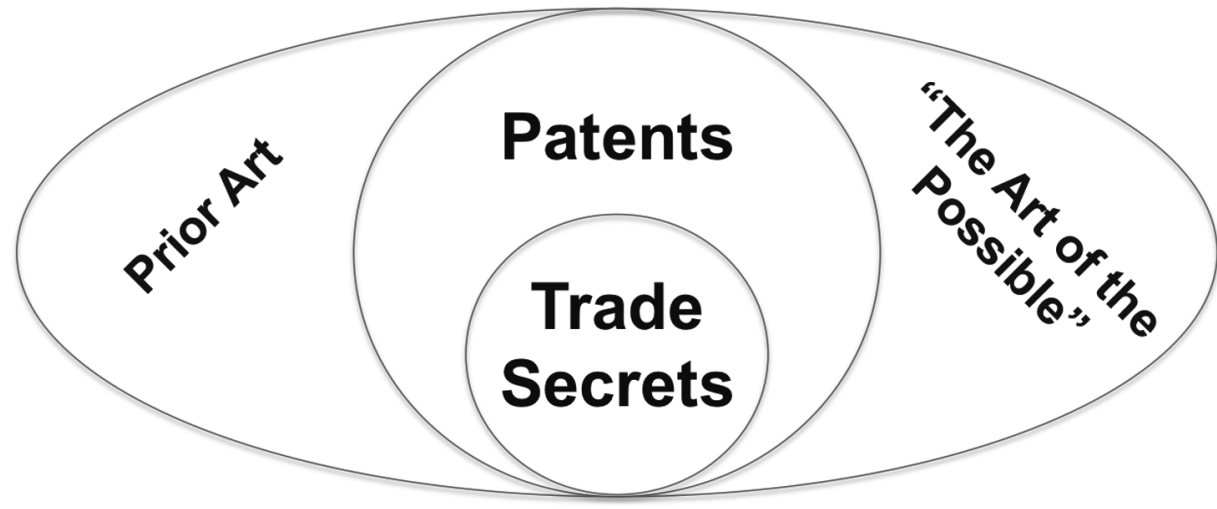

Value / Exploitation Horizon

Past

Future

Flisom went about classifying the various forms of IP as conceptualized in Figure 2:

- Trade Secrets: Key process or product knowledge that could not be reverseengineered and that the end product bore no signature of.

- Patents: Ancillary components that could be copied or could be easily transferred by personnel changing jobs.

- Prior Art in the Public Domain: The collection of knowledge upon which the technology is built, focusing on the published information of the past or current potential of the field.

Sethi made a point of capturing and documenting all of the knowledge stock of the firm and classifying each element into one of these three categories. He was acutely aware that the company could not accurately chart its own intellectual property until it had defined the origins of prior art upon which it was based. Yet, he also saw the need for another type of prior art:

'I call them the 'art of the possible.' Things that we may or may not want to pursue, things that may or may not become interesting, things that our guys in their collective wisdom perceive about what may happen in the next 20 years or longer, and we don't necessarily want to spend the money to file patents on these so what we do is we publish, and it's too far out there for us to necessarily have a business, commercial business case for that. At the same time, 20 years is, in the life of a company, not that long a period of time and you want to make sure you're futureproofing yourself. So in that case we used to just publish those in research journals and so forth. We were happy for other people to use that as well, as long as there was no blocking us in future." ${ }^{38}$ 
One danger of patenting lies in the fact that a patent can come either too soon or too late. Firms on the leading edge of technology often find that they come out with an invention before they really have a market for it, while firms that take a slow-and steady approach may find that their competitors have beaten them to the punch. ${ }^{39}$ This latter argument is much more salient given that the recent change in the U.S. patent code to first-inventor-to-file no longer protects the inventor who can demonstrate priority through an ongoing development process. In the case of nascent technologies, it may be a benefit to opt for strategic disclosure to preserve future opportunities to develop and exploit such a technology.

Flisom chose to integrate strategic disclosure in its IP strategy to firm up the foundation upon which its technology, both present and future, was based. By using a Reveal-Level strategy and filling in the gaps between what was assumed to be prior art and what was documented in technical detail, the company was assured that no competitor could "grandfather" something in and claim infringement. In choosing to publish the elements on the extreme leading edge, Sethi saw the opportunity to not only retain access to the market that would develop in the future, but also to the work of researchers who would further explore and refine those nascent technologies. ${ }^{40}$

\section{Perfect Point EDM}

Despite the vast experience and technological development of the machining industry, there are certain tasks that remain challenging even with today's most advanced machine tools. Today's super-hard metals tend to withstand the efforts of machining heads, whereas composite materials shatter or fray upon contact with them. One of the most promising technologies is electrical discharge machining (EDM), whereby the work material is sequentially eroded at the molecular level through the administration of electric "sparks." The established EDM methods, known as sinking EDM and wire EDM, have many benefits, but also severe limitations-mainly that these methods can only work with pre-defined forms or only in straight line cuts because they use electrodes that issue multiple discharges simultaneously. Through the development of its single-point discharge technology, Perfect Point EDM (PPEDM) has opened up a variety of new applications for cutting and shaping ultra-hard materials in three dimensions and to exacting standards. ${ }^{41}$

\section{Strategic Motivations of the Company}

Although PPEDM was founded with the intent of creating a robotic 3D machining tool, management soon became aware of an abundance of alternative applications for their patented core technology in diverse industry sectors. Jim Legge, the CEO and founder of PPEDM, was faced with the challenge of deciding where to take the company. Should he focus on one application in one industry sector only, or should PPEDM develop and then provide its technology to firms that supply products for individual sectors? The solution for the initial phase was to identify a ready market that would allow them to initially sell a product, thus raising capital while at the same time expanding their expertise in the core technology. 
The first product released by PPEDM, the e-Drill, had the specific function of cutting the heads off of the rivets that fasten the skins onto bodies of aircraft. On today's advanced aircraft, these panels are held on with titanium fasteners that must be removed by hand using an old-fashioned drill. One panel may have upwards of 60 fasteners, and a mere slip while drilling out any one of those could cause damage costing thousands of dollars to repair. The demand for a high-tech solution combined with PPEDM's ability to apply their technology to the problem allowed them to generate revenue while enabling the company to develop and grow largely in a pay-as-you-go mode.

\section{IP Strategy-Keep Your Options Open}

Although PPEDM chose to launch its first product in a lucrative niche market, management was fully aware that the core technology would have unique and profitable applications in several other markets. At that time, PPEDM decided to focus on strengthening its core technology, especially in the context of the primary application, while quietly developing the technology for additional applications. One potential use that Perfect Point management envisioned for its single-point EDM process was the application of precise textures to the surfaces of medical implants so that tissue would more easily bond to them. Unfortunately, one manufacturer of cardiovascular stents filed for a patent ${ }^{42}$ on exactly that method and cited the core patent underlying PPEDM's technology, effectively limiting the future potential of that market for Perfect Point. Faced with the potential of having to pay license fees and royalties if and when they chose to expand into other markets that they had not thought to protect, PPEDM's managers have since included disclosure in their IP strategy as a means to protect future options while at the same time adhering to their strategy of organic growth.

The common way to keep alternative market options open is to apply for device-and-method patents for all of the diverse market applications that might hold potential future value for the firm. This method, however, is costly and labor-intensive, so PPEDM chose instead to disclose a number of potential market applications wherein its technology could provide key advantages. An additional advantage of this Patent-Extend approach is that PPEDM could make disclosures both anonymously and through diverse outlets and it could also do so without directly stipulating its technology by name; it could disclose the methods and refer to the technology in a more generic term such as "by application of an electric discharge." In so doing, it could avoid telegraphing its intent, as patents often do, and thus reduce the risk of having a competitor block its entry into the intended market.

\section{Natural Dental Implants}

Tooth replacement is commonly a time-consuming and expensive affair, often entailing complications down the road. So it is no surprise that developing less invasive, more time-efficient procedures, and safer procedures that limit follow-on infections and costs was of significant interest in the industry. Natural Dental Implants, a Berlin-based technology start-up founded in 2006, took up the challenge. ${ }^{43}$ While traditional dental replacements consisted of a crown fixed 
by a screw and an abutment piece to the patient's jawbone, Natural Dental Implants had developed an innovative solution that would go a step further. Using x-ray images and a molded impression of the patient's teeth, the company's technology could create an exact replica of the original tooth such that a naturally formed root could be used instead of screw and abutment piece. This one-piece root would be implanted immediately after extraction of the dysfunctional tooth so that, over time, the bone would bond directly to the implant. This procedure required significantly less time for patient and doctor as well as significantly fewer complications following the implantation.

\section{Competitive Environment and Strategic Motivations of the Company}

By 2010, the company had been successful in raising sufficient seed funds to allow them to continue an aggressive development plan over the following one and a half years to create a product ready for clinical use and market launch in Germany. However, Ruedger Rubbert, the company's founder and CEO, had no illusions about the ultimate goal of the company. This was not the market for small players to turn into industry giants. The natural course of development was to create a technology-based business in a niche seen as too small or undeveloped for the few large players dominating the medical device industry. Rubbert's goal was to optimize the technological position of the company such that it would be an attractive acquisition candidate within the following three to seven years. His focus was to establish technological leadership in the largest cosmetic dentistry market in the world, that of the United States. To do so in that hugely competitive industry-where hundreds of smaller firms were trying to occupy and grow niches in order to attract one of the dozen big players dominating the field-would take more than just a good technology base.

\section{IP Strategy - Putting a Stake in the Ground}

As a serial entrepreneur with extensive IP experience, Rubbert knew that his strategic motivations needed to be supported by a strong IP strategy:

"So we developed the patent strategy to build value around our concept and protect that. The strategy is certainly to cover the biggest markets, U.S. and European, and to get a framework to protect our concept from different angles process-wise, product feature-wise, and, I would say, add to the minefield to a reasonable degree that you're recognized." ${ }^{44}$

By 2010, Natural Dental Implants had already expended about 15 percent of its seed funds on filing patents with both the U.S. and the European patent offices. Starting with the U.S. market, the company worked to extend its core patents into areas of further development using a complex web of continuation filings both in the U.S. and in Europe. By filing broad initial claims that were later adjusted, narrowed, or enhanced while the patent applications were in process, the company was able to create a solid protective space around its competitive advantage. Strategically using continuations and spinning out related applications helped establish a strong IP record and an image of strength and substance. However, this process of going back and forth between patent examiners, continued filings, and extensions was lengthy and costly. Meanwhile competitive 
pressures steadily mounted. In those instances where it became obvious or likely that competitors or companies acting in related domains could establish prior art along their strategic line of business, Natural Dental Implants decided to disclose:

"We filed the defensive application because we were not ready to file additional patents but had several ideas and saw other players adding to the minefield in all aspects of surface conditioning. ... So we started kind of searching the field, make all kind of variants out of it, and published a defensive disclosure for at least what those companies have not applied to our concepts or have not filed yet. We just kind of blocked everybody, and we hope that nobody's had an earlier publication date on their patents." 45

Using a Patent-Extend approach here provides the ability to establish a buffer zone putting distance between competitors and the company's core claims. However, given the aggressive development plan of the company and the tremendous pressure by competitors vying for attention, it also needed a time advantage. In such an environment, keeping technological advances under the radar during the 18-month post-patent-filing blackout period entailed risks. Competitors might invest in similar developments that could result in a similar patent. The resulting process of defending the company's patent and challenging the validity of the competitor's filing would be time and resource inefficient, and very likely strain the resources of the small firm. Rubbert expressed his strategy to deal with those dynamics as follows:

"In order to get the immediate benefit of a publication so that everybody else has to be inventive over what has been disclosed, we would basically file a patent and a couple days later, we would do the same exact specification as a defensive disclosure. .. . The idea is that you certainly telegraph what you are doing. . . . In terms of risks, I would rather set the bar high for followers who want to get similar patent claims through, so the earlier the publication date, the better." 46

This Patent-Reveal approach served as an effective means of warding off equal-sized competition. Instead of bearing the cost of following a development path already established as prior art by others, competitors would find greener fields by moving on to the next challenge. In this way, Natural Dental Implants was "buying" additional development time. By combining a strong proprietary base with disclosure to enable swift diffusion of its concepts, the firm was able to tip this emerging market in their direction. It established an advantage in both time and space relative to its direct competitors, thus positioning itself as an attractive acquisition target.

\section{InnoCentive}

Creativity and innovation are often collective tasks of matching problem solvers' problems with the instruments needed to solve the problems. Many firms have part of the solution formula, but lack the resources to obtain the other elements. Crowdsourcing is a growing practice that allows firms to expand their search beyond the confines of their local networks by harnessing the power of the internet 
to distribute a challenge and expand the solution set. ${ }^{47}$ Lisa Reinhold, Vice President of Client Services at InnoCentive notes:

"We find when you're able to identify the problem and peel back the onion it actually is a problem that is more portable across disciplines than the solution they were originally asking for. So what that means now is that you have more solvers, a broader community that can now weigh in and try to solve that problem, than you ever have had before." ${ }^{48}$

InnoCentive identified the need for a platform for what it calls ChallengeDriven Innovation, whereby the identity of the "seeker" (the firm looking for solutions) is hidden. It goes to great lengths to obscure the nature of the challenge so that it does not telegraph to competitors or markets. Once a challenge is announced, the seeker reviews any proposed solutions and ultimately decides on a winner. Only when the winning solution has been decided does the "solver" learn the identity of the seeker. InnoCentive then facilitates the transfer of the solution IP to the seeker, ensuring that the seeker has an unfettered right to use of and profit from the solution. Seekers may choose to maintain strict confidentiality and insist that the solver be bound by a non-disclosure agreement.

\section{IP Strategy of "Seekers"}

Despite the solution-oriented aspect of the challenges, the majority of seekers are not overly concerned with exclusivity, making it clear that their primary concern is having freedom to use the solution. In working with seekers, InnoCentive's team helps them to reduce the problem to component parts and examine which of those components they can already solve; quite often this results in the revelation that an entire process is held up by a single stumbling block. "They just need freedom to practice because it's not always core to their value proposition or what they're trying to accomplish to solve that particular problem." ${ }^{49}$ In these cases, the solution is a means whereby the seeker can derive a patentable product that is essential to the firm.

Clearly, for all parties, novelty and prior art are major concerns. Solvers are not permitted to offer solutions that are encumbered by IP restrictions, and this is easily proven by a search of IP and prior art databases. Since the challenges must be sufficiently detailed in order to steer the solvers in the right direction, and since they are posted in a public or semi-public forum, they are strategic disclosures. InnoCentive encourages seekers to be as thorough as possible. Not only does this generate a better solution set, but it also prevents any solver from claiming proprietary rights over any of the fundamental elements of the challenge itself. Likewise, InnoCentive works with the solvers to ensure that they document all elements of their solutions to ensure they are not relying on existing IP and to avail the seeker of all component elements.

The more difficult situation arises when a solution is offered that the seeker is already aware of. InnoCentive provides a caveat to seekers that it is their responsibility to provide documentation in the event that a solver makes a claim of misappropriation. This becomes all the more complex when a solver independently arrives at a solution that the seeker had already developed. InnoCentive 
advises that seekers can require solutions to be novel and can reject any solution that fails their test of novelty; however, in the event of a challenge the seeker must provide documentation-not the mere claim-of prior knowledge. While this documentation can be internal information, there must be significant proof that the documentation was generated prior to the initiation of the challenge. This is one reason that InnoCentive encourages its clients to strategically disclose the underpinnings of the challenge, thus providing incontrovertible priority. "We do have certain organizations who actually do it as part of the challenge formulation process, and then again as they understand the landscape." 50

By disclosing anonymously and distributedly, either by separating the problem into smaller challenges or by disclosing by means other than the challenge statements, the possibility of the seeker signaling intent can be eliminated while at the same time ensuring the freedom to utilize the prior art in their own future technology strategy, including patenting. This Reveal-Patent approach can be quite beneficial to the seekers.

\section{Summary: Disclosure as Part of an Integrated IP Strategy}

All of the cases above illustrate firms' use of strategies that combine trade secrecy, patenting, and at least one disclosure strategy. While the strategic motivation of each company may be different, they all share the goal of freedom to operate. Their implementation of these methods of selective revealing not only demonstrates their strategic intent, but also indicates a higher understanding of the benefits that an agile integrated IP strategy can bring.

For Flisom, the Reveal-Level approach served several important goals. First, it provided a cost efficient way to establish a level playing field on the grounds of historical prior art. Given the increased workload patent examiners face, they have precious little time to spend researching prior art. Some companies mercilessly attempt to profit from this fact, trying to get obscure prior art "grandfathered" into a patent by including it in claims and hoping to get it past the examiner. $^{51}$ Naturally this has detrimental effects if one finds oneself on the receiving end of such competitive action. Second, by choosing to reveal some of the nascent science developed, Flisom utilized disclosure as a real option to enable future patent development. Normally, real options reasoning ${ }^{52}$ requires a minimal ongoing investment thus amortizing the sunk cost over time instead of fully pursuing the development up front. By contrast, using strategic disclosure as a noncash investment on a future option, firms start their option investment program with a "down-round," but in so doing they permanently secure the option to explore and exploit the technology in the future. Similar "options thinking" characterized Perfect Point EDM's choice to engage in a Patent-Extend approach. PPEDM felt it enabled them to explore multiple opportunities and focus on the one that served the best immediate need while still preserving the ability to appropriate future returns in additional markets. ${ }^{53}$

The choice by Natural Dental Implants to integrate multiple disclosure strategies in its IP regime provided multiple tools with which it could gain advantage 
over competitors and make its product and technology portfolio attractive to potential suitors. The Patent-Extend method allowed it to create a buffer around its patented technology while the choice to Patent-Reveal served the purpose of waving the victory flag and signaling to its competitors that they would be better off moving on to the next challenge. An interesting twist on the revealing strategy is displayed in the InnoCentive case. While InnoCentive has no interest in the IP generated by the contests it hosts, its seekers may integrate a strategy of RevealPatent. This specifically acknowledges the necessity for prior art to assure clear access to the solutions provided through the services of the company. This is of crucial importance when dealing with collaborative partnerships or even licensing agreements. $^{54}$

In summary, firms that integrate strategic disclosure into their IP management strategy tend to do so in a systematic manner. The executives interviewed accept that there are concrete conditions whereby disclosure is a valuable tool and they have systems in place to take advantage of them. This entails having a set of guidelines that allow for when and how disclosure is to be accomplished. Such a system shields the managers or decision makers from backlash or being seen as downgrading value.

\section{The Double-Edged Sword of Strategic Disclosure}

Applying an effective mix of IP mechanisms requires focused attention on the interplay of the competitive setting and strategic motivations of the company as well as creative foresight of potential future options. Not doing so can lead to significant disadvantages. As an illustration, Progressive Insurance licensed a pay-as-you-drive insurance technology to Norwich Union Insurance of England. Norwich partnered with IBM to improve the technology, resulting in the integration of an encryption system-a feature Progressive had failed to include in its patent or to publish as an optional addition to its system. IBM filed a patent for the encrypted version of Progressive's pay-as-you-drive system, citing the Progressive patent as prior art. As customer adoption test showed, encryption was a key feature to diffuse the system. As Progressive had failed to secure corresponding claims, or taken the simple measure of publishing it, it was subsequently forced to pay a royalty to IBM to use its own innovation. ${ }^{55}$

Why did Progressive (and many other firms, according to our own surveys) not think about claiming future options through such simple means as strategic disclosure? As we previously stated, the dominant reason may simply be a lack of awareness. Although having proven its worth to some of the largest technology firms in the world, strategic disclosure has yet failed to gain a solid foothold in strategic practice throughout industry. That shortfall may be partially due to the fact that there is relatively little education for managers and top executives on IP strategy, and the few existing educational programs, from our experience, tend to focus on patenting at the operational level. Another reason for resistance sometimes posited by professionals is that strategic disclosure is a commitment that offers no looking back. As soon as an invention has been disclosed, the disclosed technology cannot be patented, even by the disclosing party. ${ }^{56}$ An executive from 
one disclosure firm stated that this is the hardest barrier for managers to overcome. Some managers would rather watch a competitor reduce the value of an invention to zero than consider the option of retaining the future potential to exploit that technology at the cost of the unknowable value of a nascent patent. ${ }^{57}$

Another reason why strategic disclosure may not have reached widespread use in industry may be that smaller firms tend to have less-formalized procedures for evaluating IP and thus rely more on external IP attorneys, which introduces an agency dilemma as those attorneys make money by writing patents. Furthermore, many patent attorneys are conditioned to see things in a tactical sense; without a patent there is no property to defend and no power to enforce. The fact that ownership also conveys liability, and that there is a direct correlation between the firm size of the patent holder and likelihood of being subject to litigation, ${ }^{58}$ means that an increase in a firm's patent portfolio also increases the chances of future litigationand, possibly, defense revenues for the attorney.

As one CEO pointed out:

"Lawyers do law; they don't do business provisioning, strategy, exit, valuation, those components that may be important for you. . . . as a business guy, I like to know, for example, my exit options. I want it to be clear, and the business of a lawyer is to paraphrase everything. You cannot relegate these components to the lawyers otherwise you just end up compounding your risks." ${ }^{59}$

Intellectual property is a major strategic asset for any technology firm, not simply a legal tool. Strategic IP management requires that a firm be proactive (as echoed in Cesaroni and Piccaluga in this issue ${ }^{60}$ ), allowing cross-functional teams to evaluate potential IP, train them in the strategic aspects, and set clear processes and guidelines. Appropriating value from a firm's knowledge is in fact a carefully orchestrated interplay of different functions, in which, as Conley et al. strikingly demonstrate, ${ }^{61}$ patent-based IP is only one of the many forms used. In Table 3, we propose some specific situations that might lead executives to consider either using strategic disclosure, or avoiding it. In general, if the firm has technology that is commercializable in a current market, and feels that its IP barriers are strong,

TABLE 3. Guidelines for Integrating Strategic Disclosure

\section{Consider using Strategic Disclosure as part of an integrated IP strategy when ...}

... freedom to operate is your primary concern.

... you want to reduce your patenting and litigation costs.

... you derive more revenue from product-related

services than from the product itself.

... your product can be easily reverse-engineered or invented-around.

... there are numerous and/or broad applications for the technology.

... you are not certain that your trade secrets can/will

remain secret.

... yours is a stand-alone business.

\section{Strategic Disclosure can have limits when ...}


and relies on selling access to its technology in its current markets, strategic disclosure may not be a good choice. On the other hand, if the technology will not be ready for several years, or the firm is not ready to move into other applications of its own technology, or if the option value of future market entry is high, strategic disclosure of some parts of the IP portfolio may be an excellent choice.

\section{Conclusion}

Technology firms can strategically integrate patenting and non-patenting mechanisms to effectively protect valuable technological assets and encourage growth. Strategic disclosure, and its ability to protect FTO, serves as an instrument that allows firms to appropriate returns from their inventions. The cases we have outlined show how technology managers can gauge the feasibility of different IP strategies given a particular set of motives and circumstances. As alternatives to the prevailing dichotomy of patenting vs. secrecy, these illustrative examples demonstrate how non-patenting disclosure can either substitute for resource-intensive patenting or can be combined to enhance the value of the patents. Publishing inventions-either in conjunction with existing patents, or as a substitute-can yield significant benefits in terms of speed, cost, and available options in the innovation and commercialization process, thus helping protect and strengthen the market position of firms in highly dynamic market environments.

\section{Notes}

1. Dr. Andreas Popp, Vice President Global Intellectual Property, BASF SE, telephone interview with author, February 1, 2013.

2. The qualifications for patenting are novelty, non-obviousness, and utility; the fact that a chemical is novel and has one use, such as reacting with other compounds, makes it patentable. In the case of a group of patented compounds (US-5814341, US-6162447, \& US-6162449), the utility of some 2,000 potential compositions containing the compounds had not been established. However, by publishing the compositions in an IP.com Prior Art Database Disclosure (<http://ip.com/IPCOM/000132545>) and thereby obviating their novelty, BASF prevented the possibility of being locked into a one-to-one relationship wherein BASF could only supply the otherwise holder of the patent for a given composition.

3. James G. Conley, Peter Bican, and Holger Ernst, "Value Articulation: A Framework for the Strategic Management of Intellectual Property," California Management Review, 55/4 (Summer 2013).

4. The authors would like to thank Ove Granstrand for suggesting definitions of "strategic disclosure" and "freedom to operate."

5. D. Somaya, D. Teece, and S. Wakeman, "Innovation in Multi-Invention Contexts: Mapping Solutions to Technological and Intellectual Property Complexity," California Management Review, 53/4 (Summer 2011): 47-79; D. Somaya, "Patent Strategy and Management: An Integrative Review and Research Agenda," Journal of Management, 38/4 (July 2012): 1084-1114.

6. Prior art publication and database services such as Research Disclosure and IP.com provide all patent examiners full access to their databases, allowing examiners to easily search all prior art registered with these publications.

7. D.J. Kappos and T.S. Rea, "Report on the Prior User Rights Defense," United States Patent and Trademark Office, January 2012.

8. The subtle difference of the U.S. designation of first-inventor-to-file (FITF) versus first-to-file (FTF) is that under $102(\mathrm{~b})(1 / 2)(\mathrm{B})$ the inventor has the right to publish or otherwise reveal the invention up to one year prior to filing for a patent. It has been argued that, through this exception, the FITF system has become the first-to-publish system. Brad Pedersen and Christian James Hansen, “Statutory Construction and Policy Arguments for a Symmetric Approach to 
Promulgating Guidelines for New Section 102(B) Subparagraphs (A) and (B) - The First-toPublish Grace Period Exceptions to Prior Art," October 1, 2012, available at SSRN: <http:// ssrn.com/abstract $=2155257>$.

9. Uncertainty in the patent system has a counter-intuitive effect; instead of using it less, firms are choosing to file for more patents, most of which are defensive in nature. I. Hargreaves, "Digital Opportunity: A Review of Intellectual Property and Growth," 2011, London, Intellectual Property Office, <www.ipo.gov.uk/ipreview-finalreport.pdf>. Specific institutional details of the copyright system are beyond the scope of this article.

10. S.J.H. Graham, R.P. Merges, P. Samuelson, and T. Sichelman, "High Technology Entrepreneurs and the Patent System: Results of the 2008 Berkeley Patent Survey," Berkeley Technology Law Journal, 24/4 (2009): 255-327; P. Ozcan and K.M. Eisenhardt, "Origin of Alliance Portfolios: Entrepreneurs, Network Strategies, and Firm Performance," Academy of Management Journal, 52/2 (April 2009): 246-279.

11. These are results from a survey of 98 high-tech CEOs across Europe. See J. Thiel and T. Peters, "Intellectual Property Strategy in Innovative SMEs-A Case for Strategic Disclosure," Annual Meeting of the Academy of Management, Boston, MA, 2012. In contrast, Henkel and Lernbecher find that $70 \%$ of the largest German public firms use the practice of defensive publication. $<$ http://papers.ssrn.com/sol3/papers.cfm?abstract_id=981444>.

12. S. Baker and C. Mezzetti, "Disclosure as a Strategy in the Patent Race," The Journal of Law and Economics, 48/1 (April 2005): 173-194; T. Bar, "Defensive Publications in an RED Race," Journal of Economics $\theta$ Management Strategy, 15/1 (March 2006): 229-254; E. Von Hippel and G. Von Krogh, "Free Revealing and the Private-Collective Model for Innovation Incentives," ReD Management, 36/3 (June 2006): 295-306. Our view is consistent with Dahlander and Gann in their classification of non-pecuniary revealing strategies that lead to indirect benefits for firms. L. Dahlander and D.M. Gann, "How Open Is Innovation?" Research Policy, 39/6 (July 2010): 699-709. In contrast with the above, however, we are more concerned with the different ways firms use strategic disclosure to gain competitive advantage rather than documenting its existence.

13. J. Tao, J. Daniele, E. Hummel, D. Goldheim, and G. Slowinski, “Developing an Effective Strategy for Managing Intellectual Assets," Research Technology Management, 48/1 (January/February 2005): 50-58.

14. Moreover, our ongoing research indicates that, other than for the top $1 \%$ of firms (as measured by firm size), licensing revenue potential is statistically insignificant. It is therefore questionable as to whether licensing should be included as a significant element in the IP strategies of most firms.

15. R. Katila, J. Rosenberger, and K. Eisenhardt, "Swimming with Sharks: Technology Ventures, Defense Mechanisms and Corporate Relationships," Administrative Science Quarterly, 53/2 (June 2008): 295-332.

16. E. Brouwer and A. Kleinknecht, "Innovative Output, and a Firm's Propensity to Patent: An Exploration of CIS Micro Data," Research Policy, 28/6 (August 1999): 615-624; A. Leiponen and J. Byma, "If You Cannot Block, You Better Run: Small Firms, Cooperative Innovation, and Appropriation Strategies," Research Policy, $38 / 9$ (November 2009): 1478-1488.

17. James G. Conley, Peter Bican, and Holger Ernst, "Value Articulation: A Framework for the Strategic Management of Intellectual Property," California Management Review, 55/4 (Summer 2013); Henry Chesbrough and Eric L. Chen, "Recovering Abandoned Compounds Through Expanded External IP Licensing," California Management Review, 55/4 (Summer 2013).

18. William W. Fisher III and Felix Oberholzer-Gee, "Strategic Management of Intellectual Property: An Integrated Approach," California Management Review, 55/4 (Summer 2013).

19. K. Blind, J. Edler, R. Frietsch, and U. Schmoch, "Motives to Patent: Empirical Evidence from Germany," Research Policy, $35 / 5$ (June 2006): 655-672; S.J.H. Graham and T. Sichelman, “Why Do Start-Ups Patent?" Berkeley Technology Law Journal, 23/3 (Summer 2008).

20. G. Pacheco-De-Almeida and P.B. Zemskyl, "Some Like It Free: Innovators' Strategic Use of Disclosure to Slow Down Competition," Strategic Management Journal, 33/7 (July 2012): 773-793.

21. J.E. Bessen and M.J. Meurer, Patent Failure: How Judges, Bureaucrats, and Lawyers Put Innovators at Risk (Princeton, NJ: Princeton University Press, 2008).

22. Prior art searches performed by patent offices cover existing patents and non-patent material; however, the USPTO Manual of Patent Examining Procedure section 901.03 states that "pending U.S. applications which have not been published are generally preserved in confidence and are not available as references." Thus, examiners may be uninformed as to the full state of 
prior art during this pendency period and may grant conflicting patents. Although the prior art status of the patent application is effective retroactively to the filing date, conflicting patents are not automatically rescinded and action must be initiated, usually by the initial applicant and often at significant cost to do so.

23. Kappos and Rea, op. cit.

24. R. Agarwal, M. Ganco, and R.H. Ziedonis, "Reputations for Toughness in Patent Enforcement: Implications for Knowledge Spillovers via Inventor Mobility," Strategic Management Journal, 30/13 (December 2009): 1349-1374.

25. J. Bessen and M.J. Meurer, "Do Patents Perform Like Property?" Academy of Management Perspectives, 22/3 (August 2008): 8-20; D. Encaoua, D. Guellec, and C. Martinez, "Patent Systems for Encouraging Innovation: Lessons from Economic Analysis," Research Policy, 35/9 (November 2006): 1423-1440; J. Lerner, "The Importance of Patent Scope: An Empirical Analysis," RAND Journal of Economics, 25/2 (Summer 1994): 319-333.

26. N.F. Maloney, "The Defensive Publication: A Patent Alternative," New Hampshire Business Review, 25/8 (2003): 5B.

27. Baker and Mezzetti, op. cit.

28. Fees as stated by the United States Patent and Trademark Office, <www.uspto.gov/web/offices/ ac/qs/ope/fee092611.htm>, accessed on July 15, 2012.

29. Our interview subjects indicate that this is the general range of costs for filing a single patent in a single jurisdiction, either the U.S. or EU. These figures are derived from K.A. Moore, "Worthless Patents," Berkeley Technology Law Journal, 20/4 (Fall 2005): 1521-1552.

30. E.F. Berrier, "Global Patent Costs Must Be Reduced," IDEA: The Journal of Law and Technology, 36/4 (1996): 473-511.

31. D. Lichtman, S. Baker, and K. Kraus, "Strategic Disclosure in the Patent System," Vanderbilt Law Review, 53/6 (November 2000): 2175.

32. Somaya (2012), op. cit.

33. Flisom is a spin-out of the EMPA Materials Science $\&$ Technology Research Institute, a part of the Swiss Federal Institute of Technology Domain, <www.empa.ch/plugin/template/empa/ $1197 / * /---/ l=2>$.

34. Anil Sethi, former CEO of Flisom, interview with author, Zurich, Switzerland, April 23, 2012.

35. S. Scotchmer, Innovation and Incentives (Cambridge, MA: The MIT Press, 2004).

36. One CEO of a biomedical device company informed us that a competitor had brazenly included in a claim a calibration algorithm that had been published in a textbook in the year 1926. Despite the fact that this CEO's firm had integrated it into its product and considered it to be common knowledge, the examiner was unaware of this obscure fact and subsequently granted the patent inclusive of the claim (telephone interview with unnamed CEO, February 15 , 2012).

37. Although something may be considered common knowledge if it has not previously been documented in technical detail, it could still be patented. Bessen and Meurer (2008), op. cit. As demonstration of this fact, consider U.S. Patent 6004596, a peanut butter and jelly sandwich; U.S. Patent 6360693, an "Animal Toy" which is effectively a tree branch; or even U.S. Patent 6368227, a method for swinging on a swing.

38. Sethi, op. cit.

39. J. Bessen and E. Maskinl, "Sequential Innovation, Patents, and Imitation," RAND Journal of Economics, 40/4 (Winter 2009): 611-635.

40. Although it is possible to use the patent system to disclose findings without necessarily holding the intent to patent [for a discussion on this, see J. Henkel and F. Jell, Alternative Motives to File for Patents: Profiting from Pendency and Publication," April 8, 2009, available at <http://ssrn. com/abstract=1271242>], none of the companies we spoke to had chosen such a solution. The reasons provided were: the procedural costs related to patent filings; the pendency period; and the fact that a withdrawn patent provides scientists with no reward, whereas journal publications provide reputational benefits to these inventors.

41. Case information comes from interviews and discussions with James Legge, Founder and CEO of PPEDM Inc., as well as other staff members of PPEDM as part of extended research along with consulting for which two of the authors received financial consideration.

42. United States Patent 7537610.

43. All case information comes from Natural Dental Implants' website, <http://replicatetooth.com/>, accessed on May 13, 2012, and a telephone interview with Ruedger Rubbert, Natural Dental Implants' CEO, June 22, 2010.

44. Rubbert, op. cit. 
45. Rubbert, op. cit.

46. Rubbert, op. cit.

47. A.N. Afuah and C.L. Tucci, "Crowdsourcing as a Solution to Distant Search," Academy of Management Review, 37/3 (July 2012): 355-375.

48. Lisa Reinhold, VP of Client Services, telephone interview with author, February 5, 2013.

49. Reinhold, op. cit.

50. Reinhold, op. cit.

51. Anonymous CEO, telephone interview with author, February 15, 2012. Please contact authors for more information.

52. R.G. McGrath and A. Nerkar, "Real Options Reasoning and a New Look at the R\&D Investment Strategies of Pharmaceutical Firms," Strategic Management Journal, 25/1 (January 2004): 1-21.

53. The identification of multiple market opportunities provides key benefits to entrepreneurial firms, even when they do not pursue all of them. M. Gruber, I.C. MacMillan, and J.D. Thompson, "Look before You Leap: Market Opportunity Identification in Emerging Technology Firms," Management Science, 54 (2008): 1652-1665. Thus a cost-effective means of protecting the option allows the firm to explore openly without expending resources to ensure a future right to pursue. We find other examples in the works of our colleagues in this issue, notably Henkel et al., who suggest integrating such potential even into the product development process. Joachim Henkel, Carliss Y. Baldwin, and Willy Shih, "IP Modularity: Profiting from Innovation by Aligning Product Architecture with Intellectual Property," California Management Review, 55/4 (Summer 2013).

54. The reader might see interesting parallels to the thinking of our colleagues Chesbrough and Chen in this issue. Chesbrough and Chen, op. cit.

55. Cuypers, “Founder's Knowledge: Law and Intellectual Property Protection: Reflections from a Practitioner," Venture 2006 Seminar, Zurich, 2005.

56. While the U.S. patent system allows for patenting within 12 months of publication, this is not true for the rest of the world. Hence, disclosure prior to filing a PCT or foreign patent will invalidate novelty.

57. Thomas Colson, CEO of IP.com, interview by Tilo Peters, Buffalo, NY, January 30, 2012.

58. J.O. Lanjouw and M. Schankerman, "Characteristics of Patent Litigation: A Window on Competition," RAND Journal of Economics, 32/1 (Spring 2001): 129-151.

59. Sethi, op. cit.

60. Fabrizio Cesaroni and Andrea Piccaluga, "Operational Challenges and ST's Proposed Solutions to Improve Collaboration between IP and R\&D in Innovation Processes," California Management Review, 55/4 (Summer 2013).

61. Conley et al., op. cit. 